\title{
Burkholderia phytofirmans PsJN Acclimates Grapevine to Cold by Modulating Carbohydrate Metabolism
}

\author{
Olivier Fernandez, ${ }^{1}$ Andreas Theocharis, ${ }^{1}$ Sophie Bordiec, ${ }^{1}$ Regina Feil, ${ }^{2}$ Lucile Jacquens, ${ }^{1}$ \\ Christophe Clément, ${ }^{1}$ Florence Fontaine, ${ }^{1}$ and Essaid Ait Barka ${ }^{1}$
}

\begin{abstract}
1 Université de Reims Champagne Ardenne, Unité de Recherche Vignes et Vins de Champagne-Stress et Environnement (EA 2069), UFR Sciences Exactes et Naturelles, BP 1039, 51687 Reims Cedex 2, France; ${ }^{2}$ Max Planck Institute of Molecular Plant Physiology, Am Mühlenberg 1, 14424 Potsdam, Germany
\end{abstract}

Submitted 21 September 2011. Accepted 16 November 2011.

\begin{abstract}
Low temperatures damage many temperate crops, including grapevine, which, when exposed to chilling, can be affected by symptoms ranging from reduced yield up to complete infertility. We have previously demonstrated that Burkholderia phytofirmans PsJN, a plant growth-promoting rhizobacteria (PGPR) that colonizes grapevine, is able to reduce chilling-induced damage. We hypothesized that the induced tolerance may be explained at least partly by the impact of bacteria on grapevine photosynthesis or carbohydrate metabolism during cold acclimation. To investigate this hypothesis, we monitored herein the fluctuations of photosynthesis parameters (net photosynthesis $\left[P_{n}\right]$, intercellular $\mathrm{CO}_{2}$ concentration, stomatal conductances, ФPSII, and total chlorophyll concentration), starch, soluble sugars (glucose, fructose, saccharose, mannose, raffinose, and maltose), and their precursors during 5 days of chilling exposure $\left(4^{\circ} \mathrm{C}\right)$ on grapevine plantlets. Bacterization affects photosynthesis in a non-stomatal dependent pattern and reduced long-term impact of chilling on $P_{n}$. Furthermore, all studied carbohydrates known to be involved in cold stress tolerance accumulate in nonchilled bacterized plantlets, although some of them remained more concentrated in the latter after chilling exposure. Overall, our results suggest that modification of carbohydrate metabolism in bacterized grapevine plantlets may be one of the major effects by which this PGPR reduces chilling-induced damage.
\end{abstract}

Abiotic stresses are responsible for $50 \%$ of crop loss worldwide (Boyer 1982; Bray et al. 2000; Nagarajan and Nagarajan 2010). Among them, exposure to low temperatures is one of the most damaging environmental factors affecting plants (Boyer 1982; Nagarajan and Nagarajan 2010). Upon chilling (low temperature above $0^{\circ} \mathrm{C}$ ), common temperate crops such as maize, potato, and grapevine can suffer severe damage (Ait Barka et al. 2006; McKersie and Leshem 1994; Nagarajan and Nagarajan 2010; Ruelland et al. 2009). Nevertheless, at chilling temperatures, plants may enter a process called acclimation, which improves tolerance and reduces damage due to long-term chilling exposure (Ruelland et al. 2009). Cold acclimation involves several metabolic adjustments such as i) induction of cold-specific gene expression (Chinnusamy et al. 2007; Nakashima and Yamaguchi-Shinozaki 2006; Thomashow 2010),

O. Fernandez and A. Theocharis have contributed equally to this work.

Corresponding author: E. A. Barka; E-mail: ea.barka@univ-reims.fr ii) synthesis of cold-related proteins (Janská et al. 2010; Moffatt et al. 2006; Peng et al. 2008; Ruelland et al. 2009; Sasaki et al. 2007), and iii) accumulation of osmolytes such as proline (Kamata and Uemura 2004; Kaplan et al. 2007; Ruelland et al. 2009).

Additionally, accumulation of carbohydrates is one of the most important metabolic adjustments by which plants achieve low-temperature tolerance throughout cold acclimation (Janská et al. 2010; Kaplan et al. 2004; Ruelland et al. 2009). Soluble sugar concentrations (mostly sucrose, glucose, fructose, mannose, and raffinose) drastically increase upon chilling exposure (Kaplan et al. 2004) and correlate with low-temperature tolerance in Arabidopsis thaliana (Rohde et al. 2004) as well as many crops (Gusta et al. 2004; Kamata and Uemura 2004; Koster and Lynch 1992). Soluble sugar increases during cold acclimation may originate from starch degradation (Kaplan et al. 2004) and from accumulation of several precursors such as galactinol and phosphated (G6P, G1P, F6P, and others) and nucleotided (UDPG) sugars (Kaplan et al. 2004; Ruelland et al. 2009). In contrast to many crops under cold acclimation, grapevine is characterized by simultaneous soluble sugar and starch accumulation (Ait Barka et al. 2006).

Sugars play multiple roles in low-temperature tolerance. As typical compatible osmolytes, they contribute to the preservation of water within plant cells, reducing thereby water availability for ice nucleation in the apoplast (Ruelland et al. 2009; Steponkus 1984). Sugars might protect plant cell membranes during cold-induced dehydration, replacing water molecules in establishing hydrogen bonds with lipid molecules (Ruelland et al. 2009; Uemura et al. 2003). Sugar glass-forming properties offer additional protection against cold damage, especially in woody species that can tolerate temperatures down to $-20^{\circ} \mathrm{C}$ (Hirsh 1987). Finally, sugars might exhibit reactive oxygen species (ROS)-scavenging properties (Bogdanović et al. 2008; Nishizawa et al. 2008).

Related to carbohydrate metabolism, photosynthesis is strongly affected by low temperatures. In A. thaliana, the maximum quantum efficiency of $\Phi$ PSII $(\mathrm{Fv} / \mathrm{Fm})$ is reduced by $20 \%$ (Zhang and Scheller 2004). Additionally, some photosynthesis-related genes are affected by chilling (Janská et al. 2010). In grapevine, Fv/Fm, net photosynthesis $\left(P_{n}\right)$, and stomatal conductances $\left(\mathrm{g}_{\mathrm{s}}\right)$ are reduced under chilling temperatures (Bertamini et al. 2005, 2006; Hendrickson et al. 2004).

In temperate climates, several wine-growing areas can be subjected to low temperatures during the growing season that can compromise grapevine productivity. Recently, the use of beneficial microorganisms such as plant growth-promoting rhizobacteria (PGPR) has emerged as a potential new solution 
to reduce abiotic stress-induced damage, including chilling damage (Yang et al. 2009). Some of these PGPR classified as endophytes are able to transcend the endodermis barrier, crossing from the root cortex to the vascular system, and subsequently thrive as endophytes in stem, leaves, tubers, and other organs (Compant et al. 2005a). The extent of endophytic colonization of host plant organs and tissues reflects the ability of bacteria to selectively adapt to these specific ecological niches (Gray and Smith 2005). As a result, intimate associations between bacteria and host plants can be formed without harming the plant (Compant et al. 2005a; Gray and Smith 2005; Lodewyckx et al. 2002). PGPR colonize the plant rhizosphere and positively affect their growth and responses to stress (Compant et al. 2008b; Yang et al. 2009). Surprisingly, very little is known of their influence on plant photosynthesis and primary metabolism. We have previously demonstrated that the PGPR Burkholderia phytofirmans PsJN colonizes grapevine (Compant et al. 2008a and b) and enhances several traits correlated with low-temperature tolerance (CBF gene expression, accumulation of proline, and phenolic compounds) (Ait Barka et al. 2006; Theocharis et al. 2012). We also observed that $B$. phytofirmans PsJN induces starch synthesis and enhances photosynthetic capacity after 2 weeks of chilling (Ait Barka et al. 2006). Moreover, B. phytofirmans PsJN strongly reduces longterm chilling damage (Ait Barka et al. 2006; Theocharis et al. 2012).

In order to understand how B. phytofirmans helps grapevine to withstand chilling damage, we suggest that the bacterium modulates the photosynthetic capacity or accumulation of cryoprotective soluble sugars in parallel with higher starch synthesis before or during cold acclimation. Thus, we investigated the fluctuations in photosynthesis parameters $\left(\mathrm{P}_{\mathrm{n}}\right.$, intercellular $\mathrm{CO}_{2}$ concentration $\left[\mathrm{C}_{\mathrm{i}}\right], \mathrm{g}_{\mathrm{s}}, \Phi P S I I$, and total chlorophyll concentration) as well as variations of the major carbohydrates within the first 5 days of chilling exposure.

\section{RESULTS}

\section{Changes of photosynthesis parameters} and pigment content.

Bacterized (B) plantlets at $26^{\circ} \mathrm{C}$ showed $25 \%$ lower $\mathrm{P}_{\mathrm{n}}$ (Fig. $1 \mathrm{~A})$ and slightly higher $\mathrm{C}_{\mathrm{i}}$ compared with nonbacterized (NB) ones (Fig. 1B). In contrast, $\mathrm{g}_{\mathrm{s}}$ displayed similar values in both $\mathrm{NB}$ and B plantlets (Fig. 1C). The same trend was found for ФPSII in NB and B plantlets (Fig. 1D). Regarding pigment concentration, both chlorophyll and carotenoid concentrations were lower in leaves of B plantlets (Fig. 2).

$P_{n}$ was higher in leaves of nonbacterized chilled (NBC) plantlets after 1 and 2 days at $4^{\circ} \mathrm{C}$ but, 5 days later, leaves of bacterized chilled (BC) plantlets exhibited a higher $\mathrm{P}_{n}$ (Fig. 1A). In both NBC and BC plantlets, $C_{i}$ increased while $g_{s}$ remained stable during the experiment, and ФPSII decreased (Fig. 1C and D). Additionally, chilled plantlets were characterized by a reduction of pigment concentration (Fig. 2). However, no difference was found between NBC and BC plantlets in any of these parameters upon chilling (Figs. 1 and 2).

\section{Changes of starch content.}

Under normal conditions $\left(26^{\circ} \mathrm{C}\right)$, leaves of B plantlets contained higher concentrations of starch compared with NB ones
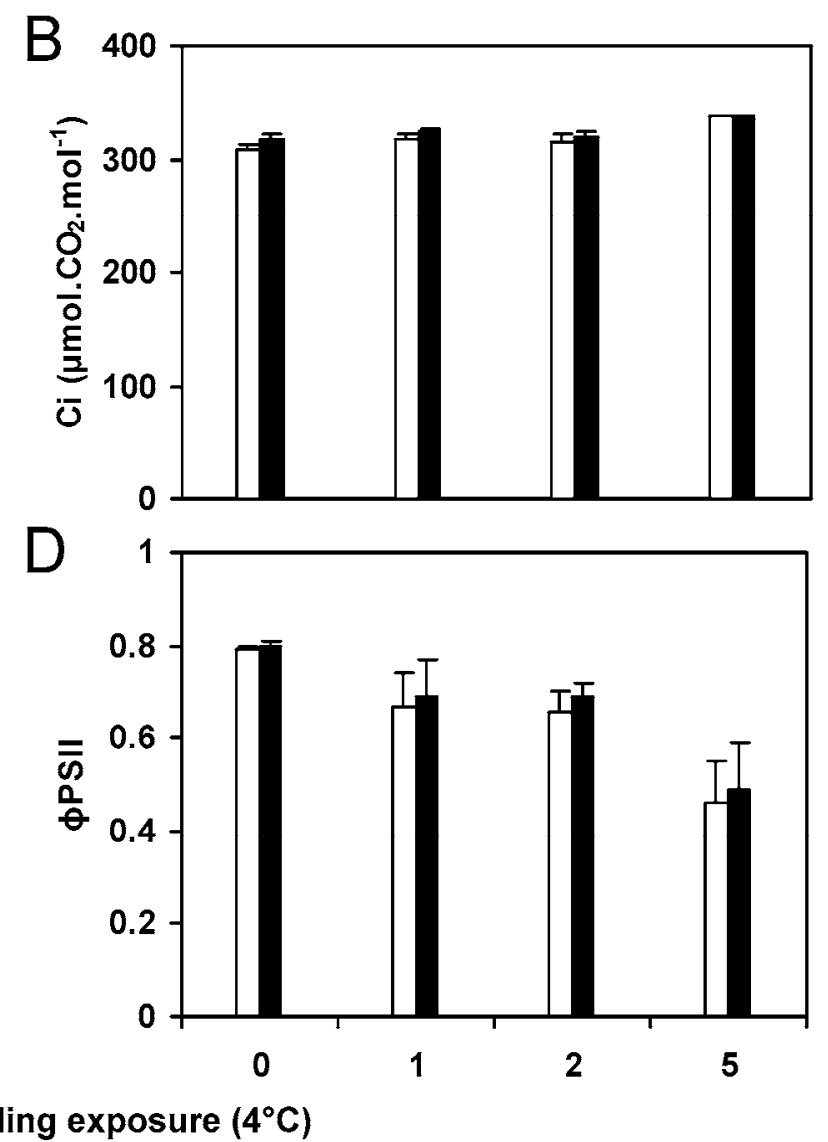

Fig. 1. Photosynthesis parameters in bacterized $(B)$ and nonbacterized $(\mathrm{NB})$ plantlets during 5 days of chilling exposure. A, Net photosynthesis $\left(\mathrm{P}_{\mathrm{n}}\right)$; $\mathbf{B}$, internal $\mathrm{CO}_{2}$ stomatal concentration $\left(\mathrm{C}_{\mathrm{i}}\right)$; $\mathbf{C}$, stomatal conductance $\left(\mathrm{g}_{\mathrm{s}}\right)$; D, effective PSII quantum yield ( ( PSII). Values are means $( \pm$ standard error) of two independent experiments. If noted, asterisks $(*)$ show significant difference $(P<0.05)$ between NB and B (day 0$)$ or NB chilled and B chilled (days 1,2 , and 5$)$ plantlets. 
(Fig. 3A). Upon chilling, starch concentration increased in both NBC and BC plantlets but faster and with higher levels in BC plantlets. After 5 days of chilling exposure, BC plantlets still contained a higher concentration of starch, close to $30 \%$ (Fig. $3 \mathrm{~A})$.

Quantitative and qualitative analysis of soluble sugars.

At $26^{\circ} \mathrm{C}$, total soluble sugars (TSS) concentration was almost twofold higher in leaves of B plantlets when compared with NB ones (Fig. 3B). Qualitatively, all soluble sugars measured were present in a higher concentration in leaves of $B$ plantlets (Fig. 4A), with the most striking differences affecting maltose, raffinose, and glucose (10-, four-, and twofold higher, respectively, than the control).

Upon chilling $\left(4^{\circ} \mathrm{C}\right)$, TSS increased in leaves of NBC and BC plantlets (Fig. 3B). During the first 2 days of chilling exposure, leaves of $\mathrm{BC}$ plantlets displayed higher soluble sugar concentration. After 5 days, leaves of NBC and BC plantlets tended to have equal TSS concentrations (Fig. 3B). Qualitatively, sugars were differentially affected by chilling exposure. To simplify analysis, data were expressed in concentration ratio of $\mathrm{NBC}$ versus $\mathrm{BC}$ (or NB versus $\mathrm{B}$ for day 0) (Fig. 5A) plantlets in addition to raw data (Table 1). Ratios of galactinol, raffinose, and, to a lesser extent, mannose remained steady during the first 2 days following chilling exposure $(45,25$, and $60 \%$ respectively) and suddenly increased after 5 days, as a consequence of their late increase in leaves of NBC plantlets (Fig. 5; Table 1). Furthermore, raffinose concentration re-
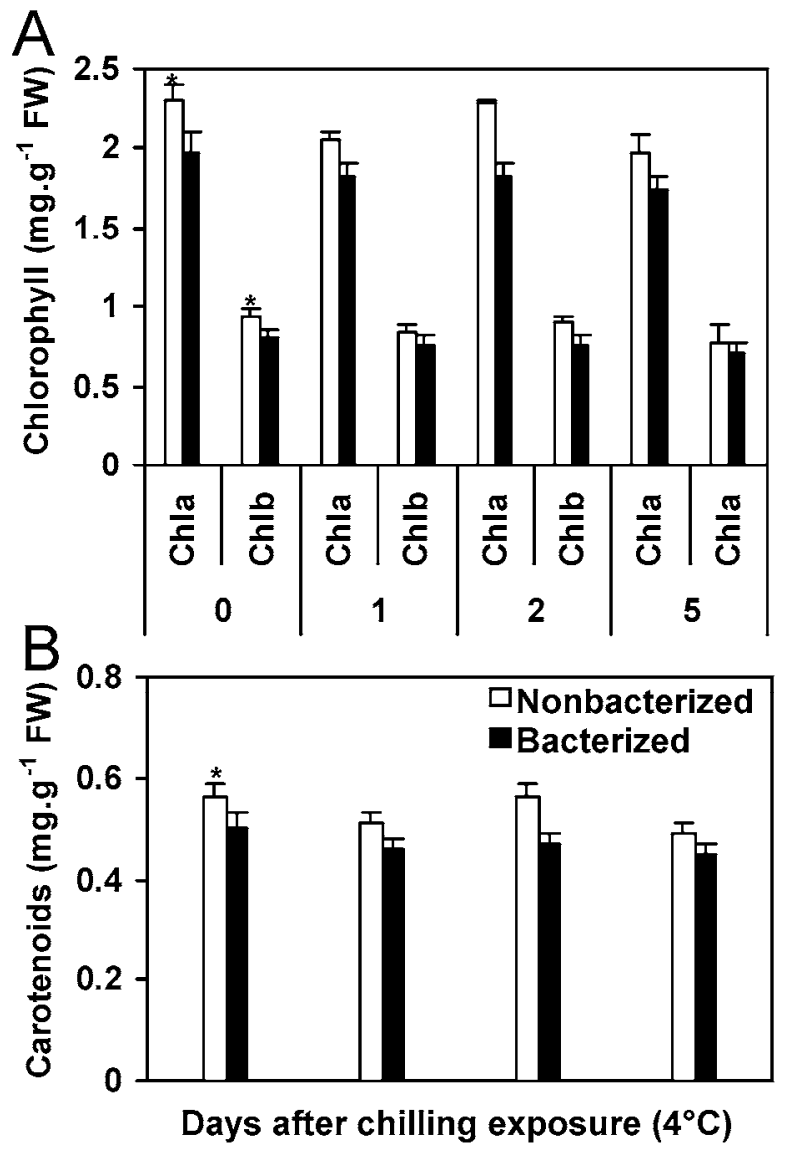

Fig. 2. Pigment concentration in bacterized (B) and nonbacterized (NB) plantlets during 5 days of chilling exposure. A, Chlorophyll a (Chla) and b (Chlb) concentration; B, carotenoids concentration. Values are means $( \pm$ standard error) of two independent experiments. If noted, asterisks $(*)$ show significant difference $(P<0.05)$ between NB and B (day 0$)$ or NB chilled and B chilled (days 1, 2, and 5) plantlets. mained higher in leaves of BC plantlets after 5 days (Fig. 5A; Table 2). Glucose and fructose ratios were gradually enhanced upon chilling (Fig. 5A), representing a faster increase in leaves of NBC plantlets (Table 1), and reached similar levels in leaves of NBC and BC plantlets after 5 days (Fig. 5A). Within 1 day, the maltose ratio was higher than $100 \%$, as a consequence of a fast increase of maltose in leaves of NBC plantlets (Fig. 5A; Table 1). Five days later, sucrose concentration was similar in leaves of NBC and BC plantlets but maltose concentration, unlike all other metabolites, remained significantly higher in NBC ones (Table 1).

\section{Quantitative and qualitative analysis of phosphated} and nucleotined sugars.

Phosphated and nucleotined sugars were analyzed to further study the dynamics of carbon metabolism in leaves before or during chilling exposure.

Concentrations of G6P, F6P, and S6P were similar in leaves of NB and $\mathrm{B}$ plantlets before exposure to chilling $\left(26^{\circ} \mathrm{C}\right)$ (Fig. 4B). In contrast, levels of G1P, M6P, UDPG, and, to a lesser extent, ADPG were lower in leaves of B plantlets (Fig. 4B).

Fluctuations of these compounds were followed during 5 days of chilling and represented as concentration ratio in leaves of NBC versus BC plantlets (NB and B plantlets for day 0) (Fig. 5B) and raw data (Table 1). All metabolites were subjected to an increase upon chilling exposure, ranging from 1.5fold (UDPG) to more than 60-fold (ADPG) after 5 days (Table 1). Interestingly, the ratio strongly increased within the first day of exposure in leaves of NBC plantlets as a consequence of a faster increase of these metabolites in NB plantlets (Fig. $5 B$, Table 1). After 2 days, all metabolites measured still displayed higher concentrations in leaves of NBC plantlets (Table 1). Such differences were no longer detected after 5 days, except for M6P (Fig. 5B; Table 1).
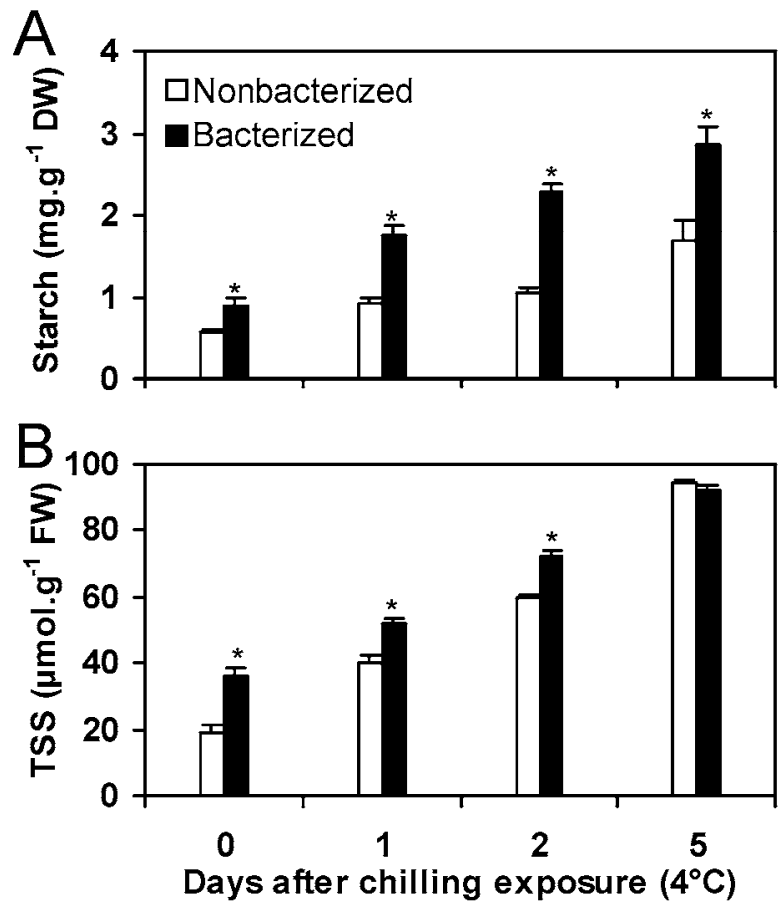

Fig. 3. A, Starch and B, total soluble sugars (TSS) in bacterized (B) and nonbacterized (NB) plantlets during 5 days of chilling exposure. TSS concentration was calculated as the sum of glucose + fructose + maltose + sucrose + raffinose + mannose. Values are means ( \pm standard error) of three independent experiments. If noted, asterisks $(*)$ show significant difference $(P<0.05)$ between NB and B (day 0$)$ or NB chilled and B chilled (days 1, 2, and 5) plantlets. 
Glycolysis fluctuations.

To gain insight into the bacterization effect on glycolysis before or during chilling treatment, the levels of phosphoenolpyruvate (PEP) and pyruvate were monitored (Fig. 6). Addition- ally, we used pyruvate/PEP and F6P/fructose 1,6-bisphosphate ratios (displayed as pyruvate kinase $[\mathrm{PK}]$ and phosphofructokinase [PFK] ratios) to estimate the activities of PK and PFK (Table 2).
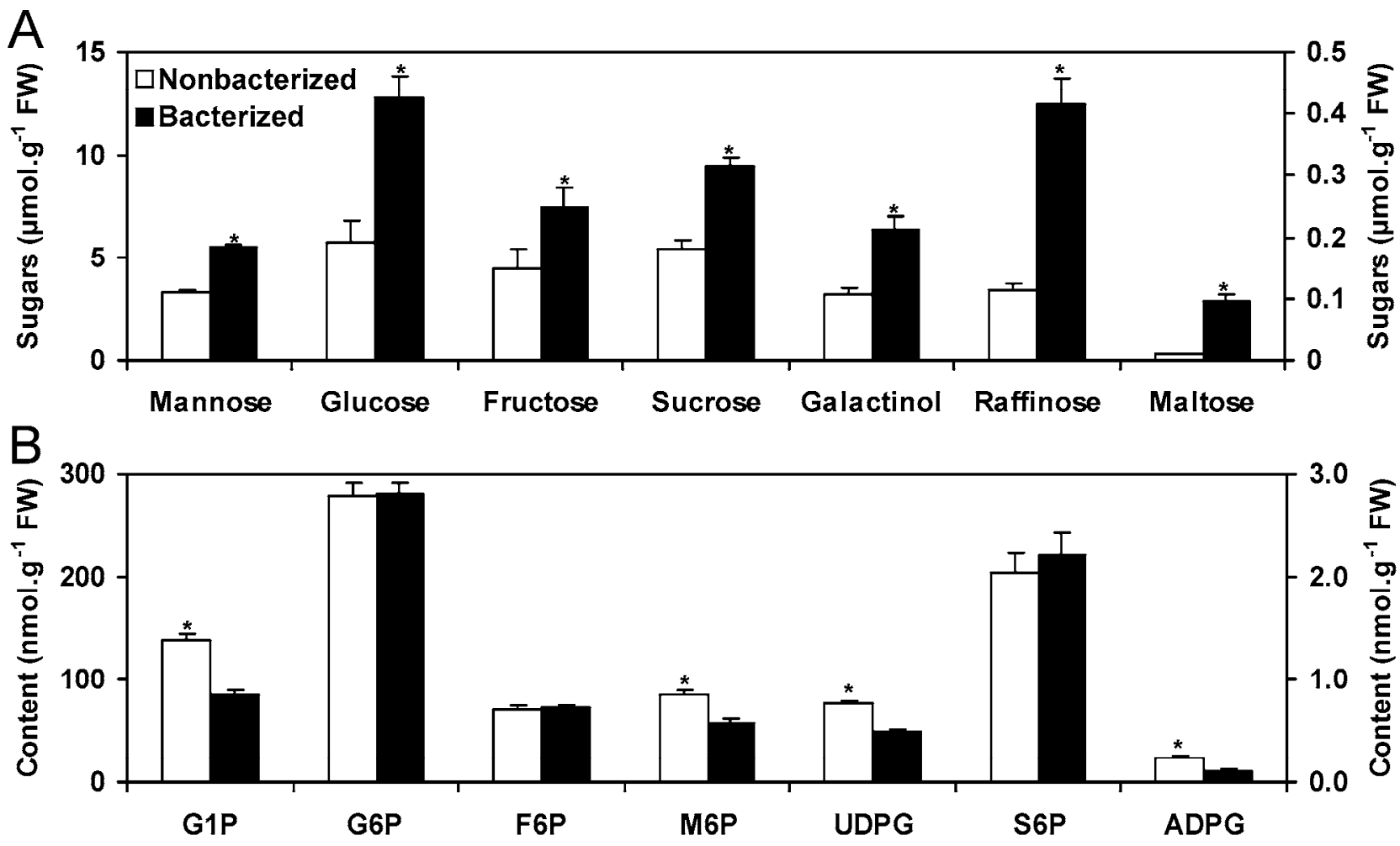

Fig. 4. A, Sugars and galactinol and B, phosphated and nucleotined intermediates concentration in bacterized (B) and nonbacterized (NB) plantlets before chilling exposure. Left axis indicates concentration for A, mannose, glucose, fructose, and sucrose and $\mathbf{B}$, G1P, G6P, F6P, M6P, and UDPG; right axis indicates concentration for A, galactinol, raffinose, and maltose and $\mathbf{B}$, S6P and ADPG. Values are means ( \pm standard error) of three independent experiments. If noted, asterisks $(*)$ show significant difference $(P<0.05)$ between NB and B plantlets.
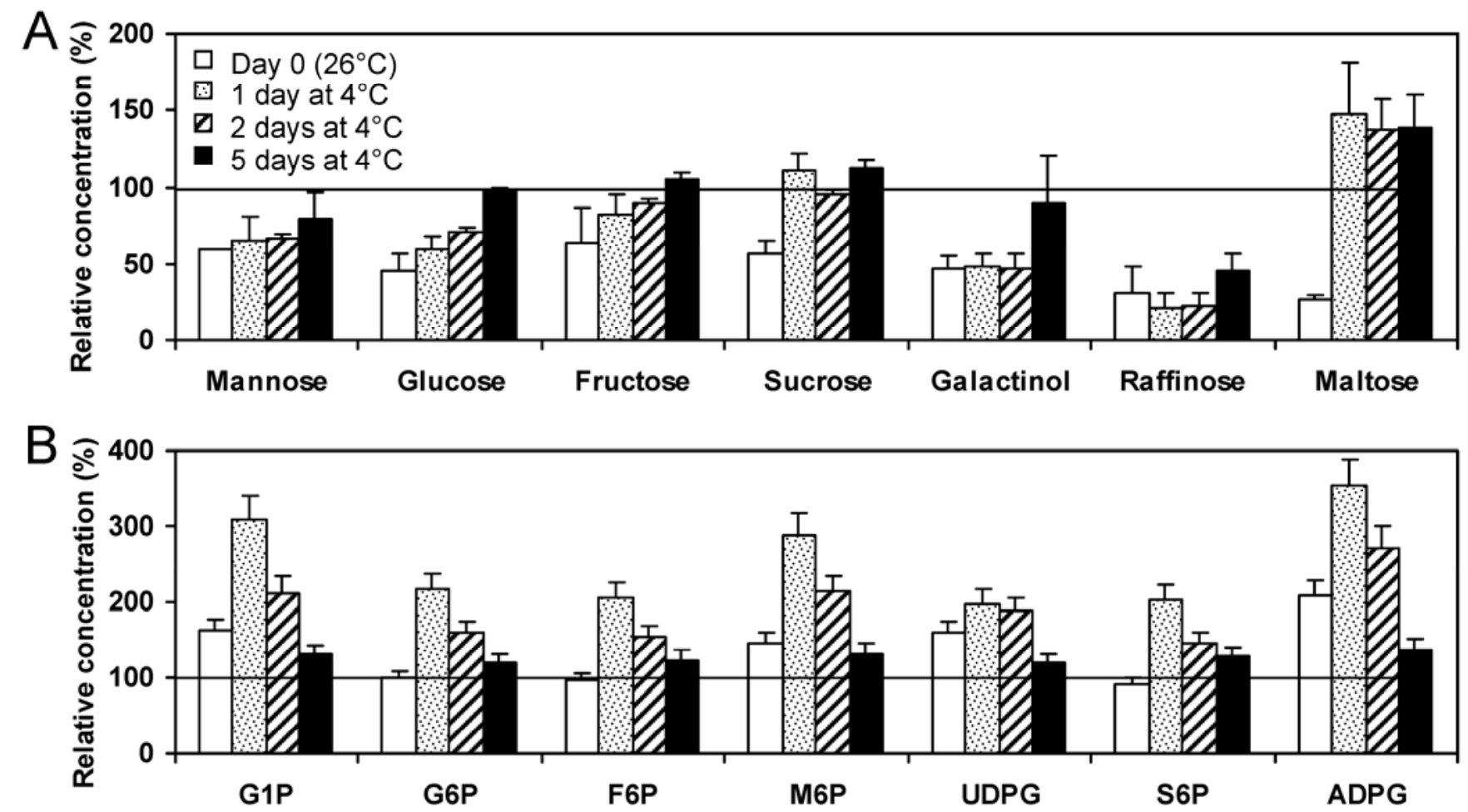

Fig. 5. Concentration ratio of $\mathbf{A}$, sugars and galactinol and $\mathbf{B}$, phosphated and nucleotined intermediates in bacterized (B) and nonbacterized (NB) plantlets during 5 days of chilling exposure $\left(4^{\circ} \mathrm{C}\right)$. At day 0 , ratio is calculated as concentration of sugars in $\mathrm{NB}$ versus $\mathrm{B}$ plantlets and at days 1,2 , and 5 as concentration of sugars in NB chilled versus B chilled plantlets. Black line indicates ratio of $100 \%$. 
At $26^{\circ} \mathrm{C}$, pyruvate and PEP concentration were higher in leaves of NB plantlets (Fig. 6). After chilling treatment $\left(4^{\circ} \mathrm{C}\right)$, these metabolites behaved differently. Pyruvate concentration drastically increased in leaves of $\mathrm{NBC}$ and $\mathrm{BC}$ plantlets but faster in NBC (Fig. 6A). Nevertheless, the level of pyruvate became similar after 5 days of chilling exposure. In contrast, PEP concentration decreased in both conditions after 2 days of $4^{\circ} \mathrm{C}$ exposure (Fig. 6B).

Regarding both PK and PFK ratios, the first one increased faster in NBC and then was overtaken by BC plantlets (Table 2 ). The PFK ratio decrease was more pronounced in leaves of NBC plantlets after 5 days at $4^{\circ} \mathrm{C}$ (Table 2).

\section{DISCUSSION}

In a previous study, we showed that $B$. phytofirmans was able to enhance tolerance of grapevine to low temperatures by cold acclimation (Ait Barka et al. 2006). To explore the mechanisms underlying bacterial-induced cold tolerance, we investigated the fluctuations of both photosynthesis and carbohydrate metabolism during acclimation.

\section{Photosynthesis parameters are modified}

in grapevine plantlets by both chilling and bacterization.

Both $\mathrm{P}_{\mathrm{n}}$ and ФPSII were markedly reduced in NBC and BC plantlets without disruption of $\mathrm{C}_{\mathrm{i}}$ and $\mathrm{g}_{\mathrm{s}}$. This is not surprising because a decrease in $\mathrm{P}_{\mathrm{n}}$ and DPSII is a classical physiological response of plants to chilling stress (Bertamini et al. 2005; Hendrickson et al. 2004). The cessation of growth resulting from cold stress reduces the capacity for energy utilization which, in turn, probably results in feedback inhibition of photosynthesis (Ruelland and Zachowski 2010).

B. phytofirmans PsJN reduced photosynthesis in a nonstomatal-dependent pattern. This is demonstrated by the fact that B plantlets displayed a lower $P_{n}$ but similar $C_{i}$ and $g_{s}$ relative to NB plantlets (Fig. 1A to C). Furthermore, bacterization affected chlorophyll concentrations but not the quantum yield of photosystem II (Figs. 1D and 2). Effects on photosynthesis parameters have been described in the literature for other beneficial plantmicrobe interactions. In contrast with our results, long-term ex-

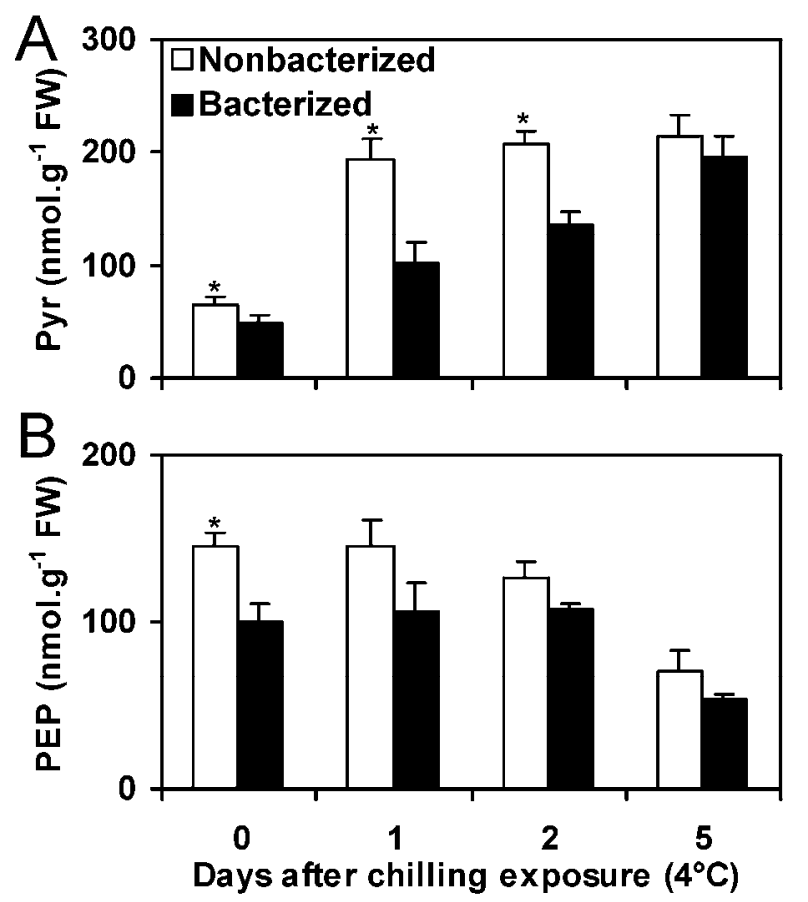

Fig. 6. Concentration of $\mathbf{A}$, pyruvate and $\mathbf{B}$, phosphoenolpyruvate in bacterized (B) and nonbacterized (NB) plantlets during 5 days of chilling exposure. Values are means $( \pm$ standard error) of four independent experiments. If noted, asterisks $(*)$ show significant difference $(P<0.05)$ between NB and B (day 0 ) or NB chilled and B chilled (days 1, 2, and 5) plantlets.

Table 1. Analysis of sugars, galactinol, and phosphated and nucleotined intermediates in bacterized and nonbacterized plantlets during 5 days of chilling exposure $^{\mathrm{a}}$

\begin{tabular}{|c|c|c|c|c|c|c|c|c|}
\hline \multirow[b]{3}{*}{ Metabolites } & \multicolumn{8}{|c|}{ Concentration $\left(\mu \mathrm{mol} \mathrm{g}^{-1} \mathrm{FW}\right)$} \\
\hline & & \multicolumn{3}{|c|}{ NBC (duration of cold exposure) } & \multirow[b]{2}{*}{ B } & \multicolumn{3}{|c|}{ BC (duration of cold exposure) } \\
\hline & NB & 1 day & 2 days & 5 days & & 1 day & 2 days & 5 days \\
\hline Mannose & $3.29 \pm 0.15$ & $3.52 \pm 0.61$ & $3.48 \mathrm{a} \pm 0.18$ & $3.69 \pm 0.14$ & $5.53 \pm 0.36$ & $5.56 \pm 0.52$ & $5.23 b \pm 0.34$ & $4.9 \pm 0.73$ \\
\hline Glucose & $5.75 \pm 1.06$ & $11.53 \mathrm{a} \pm 1.23$ & $19.01 \mathrm{a} \pm 1.27$ & $31.99 \pm 0.26$ & $12.75 \pm 1.45$ & $19.84 b \pm 1.02$ & $26.82 \mathrm{~b} \pm 0.71$ & $32.72 \pm 0.55$ \\
\hline Fructose & $4.49 \pm 0.95$ & $10.26 \pm 0.86$ & $18.32 \pm 0.78$ & $31.30 \pm 0.44$ & $7.44 \pm 0.61$ & $12.91 \pm 1.01$ & $20.52 \pm 1.4$ & $29.73 \pm 0.66$ \\
\hline Sucrose & $5.46 \pm 0.46$ & $12.84 \pm 0.63$ & $13.82 \pm 0.17$ & $18.39 \pm 0.56$ & $9.46 \pm 0.65$ & $11.80 \pm 0.98$ & $14.53 \pm 0.52$ & $16.41 \pm 1.14$ \\
\hline Galactinol & $0.11 \pm 0.02$ & $0.23 a \pm 0.06$ & $0.4 \mathrm{a} \pm 0.08$ & $0.69 \pm 0.11$ & $0.21 \pm 0.04$ & $0.47 b \pm 0.04$ & $0.99 b \pm 0.07$ & $0.88 \pm 0.16$ \\
\hline Raffinose & $0.11 \pm 0.05$ & $0.09 \mathrm{a} \pm 0.04$ & $0.22 \mathrm{a} \pm 0.07$ & $0.57 \mathrm{a} \pm 0.12$ & $0.42 \pm 0.07$ & $0.57 b \pm 0.13$ & $0.99 b \pm 0.15$ & $1.27 \mathrm{~b} \pm 0.10$ \\
\hline Maltose & $0.01 \pm 0.002$ & $1.43 \pm 0.28$ & $4.26 \pm 0.55$ & $7.90 b \pm 0.59$ & $0.05 \pm 0.01$ & $1.01 \pm 0.18$ & $3.10 \pm 0.07$ & $5.87 \mathrm{a} \pm 0.57$ \\
\hline G1P & $139 \pm 5$ & $337 b \pm 35$ & $362 b \pm 19$ & $352 \pm 42$ & $86 \pm 3$ & $109 a \pm 19$ & $170 \mathrm{a} \pm 43$ & $269 \pm 69$ \\
\hline G6P & $277 \pm 14$ & $847 b \pm 70$ & $809 b \pm 45$ & $839 \pm 50$ & $280 \pm 11$ & $391 \mathrm{a} \pm 60$ & $507 a \pm 76$ & $699 \pm 127$ \\
\hline F6P & $69 \pm 5$ & $183 b \pm 16$ & $182 b \pm 10$ & $201 \pm 11$ & $72 \pm 3$ & $89 a \pm 13$ & $118 \mathrm{a} \pm 19$ & $163 \pm 28$ \\
\hline M6P & $85 \pm 4$ & $267 b \pm 27$ & $276 b \pm 23$ & $266 b \pm 36$ & $57 \pm 4$ & $93 a \pm 16$ & $129 a \pm 18$ & $202 a \pm 53$ \\
\hline S6P & $2 \pm 0.1$ & $17.2 \mathrm{~b} \pm 1.1$ & $20.6 b \pm 0.4$ & $22.8 \pm 1.8$ & $2.2 \pm 0.1$ & $8.5 a \pm 0.5$ & $14.1 \pm 1.7$ & $17.9 \pm 1.9$ \\
\hline ADPG & $0.2 \pm 0.02$ & $4.8 b \pm 1.2$ & $7.3 b \pm 1.3$ & $12.8 \pm 2.8$ & $0.1 \pm 0.02$ & $1.3 a \pm 0.2$ & $2.6 \mathrm{a} \pm 0.9$ & $9.3 \pm 2.7$ \\
\hline UDPG & $77 \pm 3$ & $80 b \pm 4$ & $96 b \pm 3$ & $108 \pm 1$ & $48 \pm 3$ & $41 \mathrm{a} \pm 7$ & $51 \mathrm{a} \pm 12$ & $91 \pm 17$ \\
\hline
\end{tabular}

${ }^{\mathrm{a}} \mathrm{NB}=$ nonbacterized plantlets $\left(26^{\circ} \mathrm{C}\right), \mathrm{B}=$ bacterized plantlets $\left(26^{\circ} \mathrm{C}\right), \mathrm{NBC}=\mathrm{NB}$ chilled plantlets $\left(4^{\circ} \mathrm{C}\right)$, and $\mathrm{BC}=\mathrm{B}$ chilled plantlets $\left(4^{\circ} \mathrm{C}\right) . \mathrm{Values}$ are means ( \pm standard error) of three independent experiments. If noted, letters $(\mathrm{a}$ or $\mathrm{b})$ indicate different means $(P<0.05)$ between $\mathrm{BC}$ and $\mathrm{NBC}$ plantlets.

Table 2. Pyruvate kinase (PK) and phosphofructo-kinase (PFK) ratios in bacterized (B) and nonbacterized (NB) plantlets during 5 days of chilling exposure

\begin{tabular}{|c|c|c|c|c|c|c|c|c|}
\hline \multirow[b]{2}{*}{ Ratios } & \multirow[b]{2}{*}{ NB } & \multicolumn{3}{|c|}{ NBC (duration of cold exposure) } & \multirow[b]{2}{*}{ B } & \multicolumn{3}{|c|}{ BC (duration of cold exposure) } \\
\hline & & 1 day & 2 days & 5 days & & 1 day & 2 days & 5 days \\
\hline PK & 0.45 & 1.33 & 1.62 & 3.04 & 0.49 & 0.95 & 1.27 & 3.7 \\
\hline PFK & 1,655 & 3,189 & 1,283 & 261 & 1,717 & 3,363 & 1,887 & 631 \\
\hline
\end{tabular}

${ }^{\mathrm{a}} \mathrm{NB}$ and $\mathrm{B}$ plantlets at $26^{\circ} \mathrm{C}, \mathrm{NBC}=\mathrm{NB}$ chilled plantlets $\left(4^{\circ} \mathrm{C}\right)$ and $\mathrm{BC}$ : $\mathrm{B}$ chilled plantlets $\left(4^{\circ} \mathrm{C}\right)$. $\mathrm{PK}$ and $\mathrm{PFK}$ ratios were calculated as pyruvate/phosphoenolpyruvate and F6P/fructose 1,6-bisphosphate, respectively, in order to represent an estimate of PK and PFK enzyme activities. 
posure of Arabidopsis to the beneficial soil bacterium Bacillus subtilis (GB03) enhances plant photosynthetic capacity by increasing photosynthetic efficiency and chlorophyll content (Zhang et al. 2008). Such an increase in $P_{n}$ was also reported in maize plants colonized by the mycorrhiza Glomus mossea and has been linked to salt stress resistance (Sheng et al. 2008). On the other hand, $\mathrm{g}_{\mathrm{s}}$ was higher in squash colonized by the mycorrhiza Glomus intraradices (Augé et al. 2008). The observed increase, associated with a higher plant water potential, was interpreted as resulting from the symbiont improving plant gas exchange. Furthermore, the level of $g_{s}$ was higher in soybean than cowpea following colonization by Bradyrhizobium japonicum (Matiru and Dakora 2005). Overall, the impact of plantbeneficial microorganisms on plant photosynthesis parameters seems to be dependent on each associated partner.

Bacterization might help the plant to maintain a higher $P_{n}$ upon chilling. After 5 days of exposure to $4^{\circ} \mathrm{C}$, we observed that $\mathrm{P}_{\mathrm{n}}$ was higher in $\mathrm{BC}$ plantlets. This is in agreement with previous data showing higher $\mathrm{P}_{\mathrm{n}}$ in $\mathrm{BC}$ plantlets after 2 weeks of chilling exposure (Ait Barka et al. 2006). Overall, our results suggest that the presence of Burkholderia phytofirmans may help plantlets to withstand chilling damage by maintaining a higher $\mathrm{P}_{\mathrm{n}}$ when plantlets undergo a long chilling exposure and that the lower $P_{n}$ measured in $B$ plantlets does not compromise chilling-induced tolerance by the bacterium.

\section{Carbohydrates and related metabolites \\ in response to low temperatures in NBC plantlets.}

Grapevine NBC plantlets accumulate soluble sugars and starch. After 5 days of chilling, the TSS concentration increased to fivefold higher than the initial concentration (Fig. 3B). TSS are known to accumulate at low temperatures, leading to improved plant tolerance to cold in several woody plants (Leborgne et al. 1995a and b; Travert et al. 1997). Among sugars, the largest contribution was due to glucose, fructose, and sucrose. Interestingly, a shift from the production of sucrose to monosaccharides as well as production of raffinose with its precursor galactinol were detected in NBC plantlets. Similar trends occurred naturally in vineyards at the onset of cool autumn temperatures (Ait Barka and Audran 1996; Hamman et al. 1996). Only mannose remained quite stable despite the increase of its precursor (M6P) concentration. It might be possible that mannose was used as a precursor to ascorbate synthesis (Zhang et al. 2009).

In grapevine NBC plantlets, TSS and starch accumulated simultaneously. During 5 days of cold exposure, starch accumulated, as did its precursor ADPG and the first derivative sugar, maltose. Other reports have documented an increase in soluble sugars concomitant with enhanced starch concentration during cold acclimation. This phenomenon has been described in some plants such as cabbage seedlings (Sasaki et al. 1996), spinach (Guy et al. 1992), and grapevines grown in vineyards (Ait Barka and Audran 1996). In contrast, in several other species, starch is converted into soluble sugars during cold exposure, which results in a decline in starch concentration (Fischer and Höll 1991; Greer et al. 2000; Ögren 1997; Pollock and Lloyd 1987). However, the observed continuous synthesis of starch might be explained by the uptake of sucrose from the media in our experimental system.

\section{Bacterization with $B$. phytofirmans mimics some aspects of cold acclimation.}

To our knowledge, this is the first study monitoring carbohydrate concentrations in a plant colonized by PGPR during exposure to low temperature $\left(4^{\circ} \mathrm{C}\right)$.

B plantlets displayed a carbohydrate balance favorable to low-temperature tolerance. Bacterization resulted in a twofold increase in TSS and a 1.2-fold increase in starch, in agreement with our previously published results (Ait Barka et al. 2006). These features generally correlate with low-temperature tolerance observed in A. thaliana (Rohde et al. 2004). Thus, B plantlets are characterized by a higher concentration of compatible osmolytes, a key element of low-temperature tolerance (Ruelland et al. 2009). Qualitatively, all sugars known to be involved in low-temperature tolerance displayed higher concentrations in B plantlets (Fig. 4A), especially glucose, sucrose, and raffinose with its precursor, galactinol.

Sucrose is known to be an osmoprotectant, stabilizing cellular membranes and maintaining turgor in plant cells (Castonguay et al. 1995). Sucrose is one of the most easily detected sugars in cold-tolerant species (Bohnert and Sheveleva 1998). Sucrose and glucose are known to be important in low-temperature tolerance because the sfr 4 A. thaliana mutant, which exhibits reduced accumulation of both sugars, is cold sensitive (Uemura et al. 2003). Both sucrose and glucose may play a role in regulation of cold-induced expression of genes in plants (TabaeiAghdaei et al. 2003).

Raffinose is associated with low-temperature tolerance in Medicago sativa (Castonguay et al. 1995). Raffinose, with its precursor galactinol, could thus participate in limiting oxidative damage in B plantlets when submitted to chilling, as suggested recently in A. thaliana (Nishizawa et al. 2008).

The carbohydrate balance of B plantlets is also characterized by a shift from disaccharides to monosaccharides (glucose and fructose), a feature naturally occurring in vineyards during the autumn (Ait Barka and Audran 1996; Hamman et al. 1996; Uemura et al. 2003).

Bacterization might induce a change in carbohydrate balance to mimic the effect of cold acclimation. In accordance, the levels of starch, TSS, galactinol, glucose, and, to a lesser extent, fructose and sucrose were equal in B plantlets compared with 1-day-chilled NBC plantlets (Figs. 3 and 4; Table 1). This theory is supported by several points issued from this study, including i) the rapid increase in maltose content in NBC plantlets at $4^{\circ} \mathrm{C}$, which could be related to a demand for starch degradation to provide precursors for other soluble sugars (Fig. 5A; Table 1); ii) the faster and higher increase in all phosphated and nucleotided intermediates in NBC plantlets, suggestive of a stronger requirement for carbohydrate synthesis during cold acclimation relative to BC plantlets (Fig. 5B; Table 1); and iii) the faster stimulation of glycolysis in NBC plantlets, represented by a faster increase in PK activity and pyruvate accumulation, which suggests higher energy requirements for NBC plantlets when exposed to $4^{\circ} \mathrm{C}$.

Nevertheless, some aspects of carbohydrate changes induced by $B$. phytofirmans are not in agreement with this "preacclimation" hypothesis. For instance, the higher concentration of sugars in B plantlets does not compromise further accumulation of some carbohydrates following cold exposure. For example, concentrations of starch, raffinose, and mannose remained higher in BC plantlets even after 5 days of exposure to $4^{\circ} \mathrm{C}$ (Figs. 3 and 5). This could be due to a specific stimulation of this pathway by B. phytofirmans PsJN. Particularly, mannose (Streb et al. 2003; Zhang et al. 2009) as well as fructose (Bogdanović et al. 2008; Nishizawa et al. 2008), could be related to a general stimulation of ROS-scavenging properties by this bacteria via ascorbate synthesis. Improved starch synthesis without compromising synthesis of other sugars could be explained by a stimulator effect of the bacteria on both starch synthesis and degradation pathways. To date, no data are available to confirm or deny this hypothesis.

Overall, B. phytofirmans influences grapevine carbohydrate metabolism with both acquired and inducible parameters that are somehow comparable with cold acclimation and low-tem- 
perature tolerance. Therefore, this phenomenon may partly explain how the $B$. phytofirmans strain improves tolerance to chilling.

\section{MATERIALS AND METHODS}

Plant material and in vitro growth conditions.

Plantlets of Vitis vinifera 'Chardonnay' were micropropagated by nodal explants grown on $15 \mathrm{ml}$ of agar medium in 25 mm-culture tubes as described earlier (Ait Barka et al. 2006). Cultures were performed in a growth chamber at constant temperature of $26^{\circ} \mathrm{C}$ under white fluorescent light $\left(200 \mu \mathrm{mol} \mathrm{m} \mathrm{m}^{-2}\right.$ $\mathrm{s}^{-1}$ ) with $16 \mathrm{~h}$ of light per day.

\section{Bacterial inoculum and plant bacterization.}

The bacterial inoculum was produced by transferring two loops of B. phytofirmans PsJN tagged with green fluorescent protein (Sessitsch et al. 2005) to $100 \mathrm{ml}$ of King's B liquid medium in a $250-\mathrm{ml}$ Erlenmeyer flask incubated at $20^{\circ} \mathrm{C}$ at $150 \mathrm{rpm}$ for $48 \mathrm{~h}$. Bacteria were collected by centrifugation $(3,000 \times g$ for $15 \mathrm{~min})$ and washed twice with phosphatebuffer saline (PBS; $10 \mathrm{mM}, \mathrm{pH}$ 6.5). The pellet was resuspended in PBS and used as inoculum. The bacterial concentration was estimated by spectrophotometry $(600 \mathrm{~nm})$ and adjusted to $3 \times 10^{8} \mathrm{CFU} \mathrm{ml}{ }^{-1}$ with PBS (Pillay and Nowak 1997). Roots of 2-week-old plantlets were immersed in bacterial inoculum $\left(3 \times 10^{8} \mathrm{CFU} \mathrm{ml} \mathrm{m}^{-1}\right)$ or PBS (control) for $10 \mathrm{~s}$. After inoculation, plantlets were grown as described above for 4 weeks before chilling treatment.

\section{Chilling treatment.}

Half of B and NB plantlets were transferred to a cold growth chamber maintained at $4^{\circ} \mathrm{C}$ under $16 \mathrm{~h}$ of light (white fluorescent light, $200 \mu \mathrm{mol} \mathrm{m} \mathrm{m}^{-2} \mathrm{~s}^{-1}$ ) and $8 \mathrm{~h}$ of darkness, whereas the control plantlets were maintained at $26^{\circ} \mathrm{C}$. Each treatment was replicated at least three times and each replicate consisted of six plantlets.

Leaves from NB and B plantlets were sampled at 0, 1, 2, and 5 days after chilling exposure. The four conditions for plantlet treatments were abbreviated as follows: NB plantlets at $26^{\circ} \mathrm{C}(\mathrm{NB}), \mathrm{B}$ plantlets at $26^{\circ} \mathrm{C}(\mathrm{B}), \mathrm{NB}$ plantlets exposed to $4^{\circ} \mathrm{C}(\mathrm{NBC})$, and $\mathrm{B}$ plantlets exposed to $4^{\circ} \mathrm{C}(\mathrm{BC})$.

\section{Leaf gas exchanges.}

The $P_{n}, g_{s}$, and $C_{i}$ were measured with an open gas exchange system (LI-6400; Li-Cor, Lincoln, NE, U.S.A.) using equations developed by Caemmerer and Farquhar (1981). The infrared gas analysis system was equipped with a clamp-on leaf cuvette that exposed $6 \mathrm{~cm}^{2}$ of leaf area. Air temperature and humidity were maintained at $25^{\circ} \mathrm{C}$ and $30 \%$, respectively. The level of photosynthetically active radiations provided by a red and blue light-emitting diode (Li-6400-02, Li-Cor) was fixed to 1,500 $\mu \mathrm{mol} \mathrm{m} \mathrm{m}^{-2} \mathrm{~s}^{-1} \cdot \mathrm{CO}_{2}$ concentration was maintained at a constant level of $400 \mu \mathrm{mol}$ liter ${ }^{-1}$ using a $\mathrm{CO}_{2}$ injector with a highpressure liquid $\mathrm{CO}_{2}$ cartridge source (LI-6400-01; Li-Cor). Gas exchange measurements were performed on six plantlets per condition and on three leaves per plantlet.

\section{Chlorophyll fluorescence.}

Chlorophyll fluorescence reflects the functionality of the photosynthetic apparatus because it results from absorbed light. Chlorophyll fluorescence was evaluated simultaneously with gas exchange measurement at ambient $\mathrm{CO}_{2}$ concentration and temperature. Leaf chlorophyll fluorescence was quantified using a pulse-modulated fluorometer (FMS2; Hansatech, King's Lynn, U.K.). The measuring system applies an array of blue light-emitting diodes, adjusted to $10 \mathrm{~Hz}$ (peak wavelength at $470 \mathrm{~nm}$ ), for saturating light pulses. During a saturation pulse application $\left(5,000 \mu \mathrm{mol} \mathrm{m} \mathrm{m}^{-2} \mathrm{~s}^{-1}\right)$, the fluorescence yield (F) and the maximum fluorescence yield $\left(\mathrm{Fm}^{\prime}\right)$ were assessed in leaves exposed to light. The efficiency of PSII (ФPSII) represents the number of electrons transported by a PSII reaction center per mole of quanta absorbed by PSII. ФPSII was calculated as the ratio $\left(\mathrm{Fm}^{\prime}-\mathrm{F}\right) / \mathrm{Fm}^{\prime}$ according to Genty and associates (1989).

\section{Photosynthetic pigments.}

Leaf slices were dissected and pigments were extracted overnight at $4^{\circ} \mathrm{C}$ under continuous agitation in $80 \%$ (vol/vol) acetone amended with $0.5 \%$ (wt/vol) $\mathrm{MgCO}_{3}$ to prevent chlorophyll acidification. Crude extract was centrifuged at $10,000 \times g$ for $10 \mathrm{~min}$ at $4^{\circ} \mathrm{C}$ and the supernatant was used to estimate pigment concentrations spectrophotometrically according to the absorbance coefficients determined by Lichtenthaler (1987). Results were expressed in milligrams per gram of fresh weight $(\mathrm{FW})$.

\section{Soluble sugars extraction.}

Soluble sugars were extracted according to Lunn and associates (2006). Frozen leaf powder $(20 \mathrm{mg})$ was mixed in a 2-ml tube (precooled with liquid $\mathrm{N}_{2}$ ) with $350 \mu$ of ice-cold $\mathrm{CHCl}_{3} / \mathrm{CH}_{3} \mathrm{OH}$ (3:7 [vol/vol]), vigorously vortexed, and incubated at $-20^{\circ} \mathrm{C}$ for $2 \mathrm{~h}$. Afterward, $350 \mu \mathrm{l}$ of ice-cold ultrapure water (resistivity: 18.2 M $\Omega$ ) was added in the tube. Samples were vortexed and next centrifuged for $10 \mathrm{~min}$ at $14,000 \times g$ at $4^{\circ} \mathrm{C}$. Water phase was collected in a $2-\mathrm{ml}$ screw-cap tube. Then, water extraction was repeated with $300 \mu$ l of ice-cold ultrapure water. Fractions were combined and evaporated to dryness using a vacuum dryer and then redissolved in $350 \mu \mathrm{l}$ of ultrapure water (resistivity: $18.2 \mathrm{M} \Omega$ ). Before further analysis, samples were membrane-filtered (Multiscreen Ultracel-10; Millipore, Bedford, MA, U.S.A.).

\section{Sugars and primary metabolites analysis.}

Soluble sugars and galactinol. Soluble sugars and sugar alcohols were analyzed using HPAE-PAD, with a Dionex DX-500 (Dionex, Sunnyvale, CA, U.S.A.), consisting of an autosampler AS50, a gradient pump GP50, and an electrochemical detector ED50 working in pulsed amperometric mode for sugar detection. Sugars were separated using an analytical Carbo Pac PA1 column (250-by-2-mm internal diameter, $10-\mu \mathrm{m}$ pellicular resin size) (Dionex) equipped with a guard column (50-by-2-mm internal diameter, $10-\mu \mathrm{m}$ pellicular resin size) (Dionex). The column was equilibrated with $100 \mathrm{mM} \mathrm{NaOH}$ (eluent A). Then, $25 \mu \mathrm{l}$ of standard or sample was injected onto the column and the carbohydrates were separated as follows: 0- to 1-min isocratic run with $100 \mathrm{mM} \mathrm{NaOH}, 1$ - to 3.5-min linear gradient from 100 to $140 \mathrm{mM} \mathrm{NaOH}, 3.5$ - to 8-min isocratic run with $140 \mathrm{mM} \mathrm{NaOH}, 8-$ to $19-\mathrm{min}$ linear gradient from 100 to 180 $\mathrm{mM} \mathrm{NaOH}$, 19- to 20-min linear gradient from 180 to $200 \mathrm{mM}$ $\mathrm{NaOH}, 20$ - to 30-min isocratic run with $200 \mathrm{mM} \mathrm{NaOH}$ (eluent B), 30- to 31-min linear gradient from 200 to $100 \mathrm{mM} \mathrm{NaOH}$, and 31- to 40-min isocratic run with $100 \mathrm{mM} \mathrm{NaOH}$. Flow rate was set to $0.3 \mathrm{ml} \mathrm{min}^{-1}$ and assays were performed at room temperature. Soluble sugar standards (Sigma, St. Louis) were used for external calibration. Data were collected and processed using chromeleon software, version 6.8 (Dionex). Results were expressed in micromoles per gram $\mathrm{FW}$.

Other metabolites. Phosphated and nucleotined sugars, as well as pyruvate and PEP, were assayed in leaf extract using a Dionex high-performance liquid chromatography system coupled to a Finnigan TSQ Quantum MS-Q3 apparatus (ThermoFinnigan, Waltham, MA, U.S.A.) according to Lunn and associates (2006). 
Starch extraction and analysis.

Leaf powders of the different conditions were resuspended at $4^{\circ} \mathrm{C}$ in a mortar containing $0.1 \mathrm{M}$ phosphate buffer, $\mathrm{pH}$ 7.5. The homogenates were centrifuged at $12,000 \times g$ for $15 \mathrm{~min}$, and the pellets were used for starch analysis. The collected pellets were resuspended in dimethyl sulfoxide- $8 \mathrm{M}$ hydrochloric acid (4:1 [vol/vol]). Starch was dissolved over $30 \mathrm{~min}$ at $60^{\circ} \mathrm{C}$ under continual agitation $(60 \mathrm{rpm})$, then centrifuged for $15 \mathrm{~min}$ at $12,000 \times \mathrm{g}$. Supernatant $(100 \mu \mathrm{l})$ was mixed with $100 \mu \mathrm{l}$ of iodine- $\mathrm{HCl}$ solution $\left(0.06 \% \mathrm{KI}\right.$ and $0.003 \% \mathrm{I}_{2}$ in $0.05 \mathrm{M} \mathrm{HCl}$ ) and $1 \mathrm{ml}$ of distilled water. The absorbance was read at $600 \mathrm{~nm}$ after $15 \mathrm{~min}$ of incubation at room temperature. Results were expressed in milligrams per gram of dry weight (DW).

\section{Statistical analysis.}

Results were replicated in two or three independent experiments for photosynthesis measurement or carbohydrate analysis, respectively. Standard analysis of the variance ( $t$ test) and a Tukey test were performed with Kyplot software to assess the significance of the treatment means at $P<0.05$ level.

\section{ACKNOWLEDGMENTS}

We thank Europol Agro for funding this work, B. Courteaux for help in maintaining grapevine plantlets culture, and J. E. Lunn for allowing us to use the MPI-MP Gölm facility.

\section{LITERATURE CITED}

Ait Barka, E., and Audran, J. 1996. Responses of Champagne grapevines to negative temperatures: Effect of controlled chilling on bud carbohydrate reserves before and after budbreak. Can. J. Bot. 74:492-505.

Ait Barka, E., Nowak, J., and Clément, C. 2006. Enhancement of chilling resistance of inoculated grapevine plantlets with a plant growth-promoting rhizobacterium, Burkholderia phytofirmans strain PsJN. Appl. Environ. Microbiol. 72:7246-7252.

Augé, R., Toler, H., Sams, C., and Nasim, G. 2008. Hydraulic conductance and water potential gradients in squash leaves showing mycorrhizainduced increases in stomatal conductance. Mycorrhiza 18:115-121.

Bertamini, M., Muthuchelian, K., Rubinigg, M., Zorer, R., and Nedunchezhian, N. 2005. Low-night temperature (LNT) induced changes of photosynthesis in grapevine (Vitis vinifera L.) plants. Plant Physiol. Biochem. 43:693-699.

Bertamini, M., Muthuchelian, K., Rubinigg, M., Zorer, R., Velasco, R., and Nedunchezhian, N. 2006. Low-night temperature increased the photoinhibition of photosynthesis in grapevine (Vitis vinifera L. cv. Riesling) leaves. Environ. Exp. Bot. 57:25-31.

Bogdanović, J., Mojović, M., Milosavić, N., Mitrović, A., Vučinić, Ž., and Spasojević, I. 2008. Role of fructose in the adaptation of plants to coldinduced oxidative stress. Eur. Biophys. J. 37:1241-1246.

Bohnert, H. J., and Sheveleva, E. 1998. Plant stress adaptations-making metabolism move. Curr. Opin. Plant Biol. 1:267-274.

Boyer, J. S. 1982. Plant productivity and environment. Science 218:443448.

Bray, E., Bailey-Serres, J., and Weretilnyk, E. 2000. Responses to abiotic stresses. Pages 1158-1203 in: Biochemistry and Molecular Biology of Plants. B. Buchanan, W. Gruissem, and R. Jones, eds. American Society of Plant Physiology, Rockville, MD, U.S.A.

Caemmerer, S., and Farquhar, G. D. 1981. Some relationships between the biochemistry of photosynthesis and the gas exchange of leaves. Planta 153:376-387.

Castonguay, Y., Nadeau, P., Lechasseur, P., and Chouinard, L. 1995. Differential accumulation of carbohydrates in alfalfa cultivars on contrasting winter hardiness. Crop Sci. 35:509-516.

Chinnusamy, V., Zhu, J., and Zhu, J.-K. 2007. Cold stress regulation of gene expression in plants. Trends Plant Sci. 12:444-451.

Compant, S., Duffy, B., Nowak, J., Clément, C., and AitBarka, E. 2005a. Use of plant growth-promoting bacteria for biocontrol of plant diseases: Principles, mechanisms of action, and future prospects. Appl. Environ. Microbiol. 71:4951-4959.

Compant, S., Reiter, B., Sessitsch, A., Nowak, J., Clément, C., and Ait Barka, E. 2005b. Endophytic colonization of Vitis vinifera L. by plant growth-promoting bacterium Burkholderia sp. strain PsJN. Appl. Environ. Microbiol. 71:1685-1693.
Compant, S., Kaplan, H., Sessitsch, A., Nowak, J., Ait Barka, E., and Clément, C. 2008a. Endophytic colonization of Vitis vinifera L. by Burkholderia phytofirmans strain PsJN: From the rhizosphere to inflorescence tissues. FEMS Microbiol. Ecol. 63:84-93.

Compant, S., Nowak, J., Coenye, T., Clément, C., and Ait Barka, E. 2008b. Diversity and occurrence of Burkholderia spp. in the natural environment. FEMS Microbiol. Rev. 32:607-626.

Fischer, C., and Höll, W. 1991. Food reserves of Scots pine (Pinus sylvestris L.). Trees Struct. Funct. 5:187-195.

Genty, B., Briantais, J.-M., and Baker, N. R. 1989. The relationship between the quantum yield of photosynthetic electron transport and quenching of chlorophyll fluorescence. BBA Gen. Subjects 990:87-92.

Gray, E. J., and Smith, D. L. 2005. Intracellular and extracellular PGPR: Commonalities and distinctions in the plant-bacterium signaling processes. Soil Biol. Biochem. 37:395-412.

Greer, D. H., Robinson, L. A., Hall, A. J., Klages, K., and Donnison, H. 2000. Frost hardening of Pinus radiata seedlings: Effects of temperature on relative growth rate, carbon balance and carbohydrate concentration. Tree Physiol. 20:107-114.

Gusta, L. V., Wisniewski, M., Nesbitt, N. T., and Gusta, M. L. 2004. The effect of water, sugars, and proteins on the pattern of ice nucleation and propagation in acclimated and non-acclimated canola leaves. Plant Physiol. 135:1642-1653.

Guy, C., Haskell, D., Neven, L., Klein, P., and Smelser, C. 1992. Hydration-state-responsive proteins link cold and drought stress in spinach. Planta 188:265-270.

Hamman, R. A., Jr., Dami, I. E., Walsh, T. M., and Stushnoff, C. 1996. Seasonal carbohydrate changes and cold hardiness of Chardonnay and Riesling grapevines. Am. J. Enol. Vitic. 47:31-36.

Hendrickson, L., Ball, M. C., Wood, J. T., Chow, W. S., and Furbank, R. T. 2004. Low temperature effects on photosynthesis and growth of grapevine. Plant Cell Environ. 27:795-809.

Hirsh, A. G. 1987. Vitrification in plants as a natural form of cryoprotection. Cryobiology 24:214-228.

Janská, A., Maršík, P., Zelenková, S., and Ovesná, J. 2010. Cold stress and acclimation-what is important for metabolic adjustment? Plant Biol. 12:395-405.

Kamata, T., and Uemura, M. 2004. Solute accumulation in wheat seedlings during cold acclimation: Contribution to increased freezing tolerance. CryoLetters 25:311-322.

Kaplan, F., Kopka, J., Haskell, D. W., Zhao, W., Schiller, K. C., Gatzke, N., Sung, D. Y., and Guy, C. L. 2004. Exploring the temperature-stress metabolome of Arabidopsis. Plant Physiol. 136:4159-4168.

Kaplan, F., Kopka, J., Sung, D. Y., Zhao, W., Popp, M., Porat, R., and Guy, C. L. 2007. Transcript and metabolite profiling during cold acclimation of Arabidopsis reveals an intricate relationship of cold-regulated gene expression with modifications in metabolite content. Plant J. 50:967981.

Koster, K. L., and Lynch, D. V. 1992. Solute accumulation and compartmentation during the cold acclimation of puma rye. Plant Physiol. 98:108-113.

Leborgne, N., Teulières, C., Cauvin, B., Travert, S., and Boudet, A. M 1995a. Carbohydrate content of Eucalyptus gunnii leaves along an annual cycle in the field and during induced frost-hardening in controlled conditions. Trees Struct. Funct. 10:86-93.

Leborgne, N., Teulieres, C., Travert, S., Rols, M.-P., Teissie, J., and Boudet, A. M. 1995b. Introduction of specific carbohydrates into Eucalyptus gunnii cells increases their freezing tolerance. Eur. J. Biochem. 229:710-717

Lichtenthaler, H. K. 1987. Chlorophylls and carotenoids: Pigments of photosynthetic biomembranes. Pages 350-382 in: Methods in Enzymology L. Packer and R. Douce, eds. Academic Press, San Diego, CA, U.S.A.

Lodewyckx, C., Vangronsveld, J., Porteous, F., Moore, E. R. B., Taghavi, S., Mezgeay, M., and van der Lelie., D. 2002. Endophytic bacteria and their potential applications. Crit. Rev. Plant Sci. 21:583-606

Lunn, J. E., Feil, R., Hendriks, J. H. M., Gibon, Y., Morcuende, R., Osuna, D., Scheible, W.-R., Carillo, P., Hajirezaei, M.-R., and Stitt, M. 2006. Sugar-induced increases in trehalose 6-phosphate are correlated with redox activation of ADP-glucose pyrophosphorylase and higher rates of starch synthesis in Arabidopsis thaliana. Biochem. J. 397:139-148.

Matiru, V. N., and Dakora, F. D. 2005. Xylem transport and shoot accumulation of lumichrome, a newly recognized rhizobial signal, alters root respiration, stomatal conductance, leaf transpiration and photosynthetic rates in legumes and cereals. New Phytol. 165:847-855.

McKersie, B. D., and Leshem, Y. Y. 1994. Stress and Stress Coping in Cultivated Plants. Kluwer Academic Publishers, Dordrecht, The Netherlands.

Moffatt, B., Ewart, V., and Eastman, A. 2006. Cold comfort: Plant antifreeze proteins. Physiol. Plant. 126:5-16.

Nagarajan, S., and Nagarajan, S. 2010. Abiotic tolerance and crop improvement. Pages 1-11 in: Abiotic Stress Adaptation in Plants: Physiological, 
Molecular and Genomic Foundation. A. Pareek, S. K. Sopory, and H. J. Bohnert, eds. Springer, Dordrecht, The Netherlands.

Nakashima, K., and Yamaguchi-Shinozaki, K. 2006. Regulons involved in osmotic stress-responsive and cold stress-responsive gene expression in plants. Physiol. Plant. 126:62-71.

Nishizawa, A., Yabuta, Y., and Shigeoka, S. 2008. Galactinol and raffinose constitute a novel function to protect plants from oxidative damage. Plant Physiol. 147:1251-1263.

Ögren, E. 1997. Relationship between temperature, respiratory loss of sugar and premature dehardening in dormant Scots pine seedlings. Tree Physiol. 17:47-51.

Peng, Y., Reyes, J. L., Wei, H., Yang, Y., Karlson, D., Covarrubias, A. A. Krebs, S. L., Fessehaie, A., and Arora, R. 2008. RcDhn5, a cold acclimation-responsive dehydrin from Rhododendron catawbiense rescues enzyme activity from dehydration effects in vitro and enhances freezing tolerance in RcDhn5-overexpressing Arabidopsis plants. Physiol. Plant. 134:583-597.

Pillay, V. K., and Nowak, J. 1997. Inoculum density, temperature, and genotype effects on in vitro growth promotion and epiphytic and endophytic colonization of tomato (Lycopersicon esculentum L.) seedlings inoculated with a pseudomonad bacterium. Can. J. Microbiol. 43:354-361.

Pollock, C. J., and Lloyd, E. J. 1987. The effect of low temperature upon starch, sucrose and fructan synthesis in leaves. Ann. Bot. 60:231-235.

Rohde, P., Hincha, D. K., and Heyer, A. G. 2004. Heterosis in the freezing tolerance of crosses between two Arabidopsis thaliana accessions (Columbia-0 and C24) that show differences in non-acclimated and acclimated freezing tolerance. Plant J. 38:790-799.

Ruelland, E., and Zachowski, A. 2010. How plants sense temperature. Environ. Exp. Bot. 69:225-232.

Ruelland, E., Vaultier, M.-N., Zachowski, A., Hurry, V., Kader, J.-C., and Delseny, M. 2009. Cold signalling and cold acclimation in plants. Pages 35-150 in: Advances in Botanical Research. J.-C. Kader and M. Delseny, eds. Academic Press, London.

Sasaki, H., Ichimura, K., and Oda, M. 1996. Changes in sugar content during cold acclimation and deacclimation of cabbage seedlings. Ann. Bot. 78:365-369.

Sasaki, K., Kim, M.-H., and Imai, R. 2007. Arabidopsis COLD SHOCK DOMAIN PROTEIN2 is a RNA chaperone that is regulated by cold and developmental signals. Biochem. Biophys. Res. Commun. 364:633638.

Sessitsch, A., Coenye, T., Sturz, A.V., Vandamme, P., Barka, E. A., Salles, J. F., Van Elsas, J. D., Faure, D., Reiter, B., Glick, B. R., Wang-Pruski, G., and Nowak, J. 2005. Burkholderia phytofirmans sp. nov., a novel plant-associated bacterium with plant-beneficial properties. Int. J. Syst. Evol. Microbiol. 55:1187-1192.

Sheng, M., Tang, M., Chen, H., Yang, B., Zhang, F., and Huang, Y. 2008. Influence of arbuscular mycorrhizae on photosynthesis and water status of maize plants under salt stress. Mycorrhiza 18:287-296.

Steponkus, P. L. 1984. Role of the plasma membrane in freezing injury and cold acclimation. Annu. Rev. Plant Physiol. 35:543-584.

Streb, P., Aubert, S., Gout, E., and Bligny, R. 2003. Cold- and lightinduced changes of metabolite and antioxidant levels in two high mountain plant species Soldanella alpina and Ranunculus glacialis and a lowland species Pisum sativum. Physiol. Plant. 118:96-104.

Tabaei-Aghdaei, S. R., Pearce, R. S., and Harrison, P. 2003. Sugars regulate cold-induced gene expression and freezing-tolerance in barley cell cultures. J. Exp. Bot. 54:1565-1575.

Theocharis, A., Bordiec, S., Fernandez, O., Paquis, S., Dhondt-Cordelier, S., Baillieul, F., Clément, C., and Ait Barka, E. 2012. Burkholderia phytofirmans PsJN primes Vitis vinifera L. and confers a better tolerance to low non-freezing temperatures. Mol. Plant-Microbe Interact. 25:241249.

Thomashow, M. F. 2010. Molecular basis of plant cold acclimation: Insights gained from studying the $\mathrm{CBF}$ cold response pathway. Plant Physiol. 154:571-577.

Travert, S., Valerio, L., Fouraste, I., Boudet, A. M., and Teulieres, C. 1997. Enrichment in specific soluble sugars of two Eucalyptus cell-suspension cultures by various treatments enhances their frost tolerance via a non-colligative mechanism. Plant Physiol. 114:1433-1442.

Uemura, M., Warren, G., and Steponkus, P. L. 2003. Freezing sensitivity in the sfr4 mutant of Arabidopsis is due to low sugar content and is manifested by loss of osmotic responsiveness. Plant Physiol. 131:18001807.

Yang, J., Kloepper, J.W., and Ryu, C.-M. 2009. Rhizosphere bacteria help plants tolerate abiotic stress. Trends Plant Sci. 14:1-4.

Zhang, H., Xie, X., Kim, M.-S., Kornyeyev, D. A., Holaday, S., and Paré, P. W. 2008. Soil bacteria augment Arabidopsis photosynthesis by decreasing glucose sensing and abscisic acid levels in planta. Plant $\mathbf{J}$. 56:264-273.

Zhang, S., and Scheller, H. V. 2004. Photoinhibition of photosystem I at chilling temperature and subsequent recovery in Arabidopsis thaliana. Plant Cell Physiol. 45:1595-1602.

Zhang, W., Lorence, A., Gruszewski, H. A., Chevone, B. I., and Nessler, C. L. 2009. AMR1, an Arabidopsis gene that coordinately and negatively regulates the mannose/L-galactose ascorbic acid biosynthetic pathway. Plant Physiol. 150:942-950. 